\title{
Prospective Social Studies Teachers' Evaluations of Their Own Oral History Experiences Related to Turkey's Recent History
}

\author{
Hülya Çelik \\ Correspondence: Hülya Çelik, Sakarya University, Faculty of Education, Sakarya, Turkey. \\ Received: July 19, 2018 \\ Accepted: August 16, $2018 \quad$ Online Published: August 28, 2018 \\ doi:10.11114/jets.v6i10.3457 \\ URL: https://doi.org/10.11114/jets.v6i10.3457
}

\begin{abstract}
This study examined how prospective social studies teachers evaluate their experiences conducting oral histories regarding Turkey's recent history. The research was completed in a course called History of the Republic of Turkey in the Faculty of Education at Sakarya University. Thirty-four social studies teacher candidates participated in the study. Based on a phenomenological research design (a qualitative research method), the data were obtained via semi-structured interviews consisting of 5 questions developed for this study. Content analysis was used to analyze the data. The prospective social studies teachers reported that their experiences completing oral histories related to recent Turkish history positively affected their views of the study of history and that their oral history experiences exposed them to diverse perspectives. The primary difficulties they encountered conducting their oral histories concerned the source persons they did oral histories. They also reported that they would like to practice oral history in their future social studies classes.
\end{abstract}

Keywords: oral history, recent history, prospective social studies teachers

\section{Introduction}

The study of recent history is prone to controversy. In fact, no consensus exists among historians regarding what actually constitutes recent history. Many believe that the term should simply refer to the period in which a historian has lived, focusing on tracing the events through that period and identifying the origins of given problems (Acun, 1998). Critiques of the field of recent history do not focus solely on the absence of clear time delineations; some contend the field lacks objectivity because it recounts contemporaneous events, aligning it more closely with the study of politics or other social sciences. Since recent history addresses the most recent epoch, the recollections of people who influence, direct, and witness events are the most important sources of information. Thus, oral history serves as one of the most important methods of revealing information about recent history.

As a research method, oral history contributes to the construction of the histories of societies by collecting personal testimonies regarding particular epochs or extracting and evaluating experiences from the depths of memory (Ritchie, 2003; Yow, 2005; Çakmak, 2011). Oral historians record interviews with persons involved in historical events; the voice recordings obtained via interviews constitute the material of the oral history. Historians then convert audio recordings into written text. The most important difference between classical historiography and oral history is that oral histories foreground the experiences of individuals (Sağlam, 2010). Oral histories rely on the collection of living people's memories of events in the context of their life stories. The basic source of oral history is the people who recount their memories of the past. Oral histories provide historians detailed information about individual experiences of historical events. Beyond serving as a means of collecting material, they contribute to the process of giving meaning to the past (Caunce, 2000; Thomson, \& Bornat, 2017).

Though widely used in the historiography of oral sources such as epics and tales, the modern iteration of oral history is quite new in Turkey. Oral history became increasingly popular following the 1980s, as interest in subjective personal testimonies in the study of institutions, workplaces, immigration, and regional history grew. In this period, university students began completing theses based on oral histories and courses began providing instruction in oral history practice. The History Foundation in Turkey has been an important contributor to oral history studies. In addition to creating an oral history archive, the History Foundation, which supported oral histories in many institutions' historical writing projects, has produced copyrighted translations related to oral history (Metin, 2002). In addition to diverse critiques and newly developed methods, studies of oral history continue to attract growing attention.

Oral history also plays an important role in education. Studies have shown that oral histories are a powerful pedagogical 
tool in developing historical understanding and important learning skills (Crocco, 1998; Ross, 1998; Busby, \& Hubbard, 2007; Dutt-Doner, Allen \& Campanaro, 2016). Oral history is often emphasized both in studies of the history of education (Güçlï, 2013) and as an educational method in the teaching of social studies and history (Siler, 1996; Huerta \& Flemmer, 2000; Jenks, 2010; Beldağ \& Balc1, 2017). Beginning in primary school, social studies classes could expose children to oral history in relation to their families and immediate environments. Education regarding oral history methods encompasses designing the interview process, preparing interview questions, recording interviews with video or audio recorders, and planning and writing reports on the data obtained from the interviews using evidence-based reasoning skills. Oral history projects are important instruments for education. In oral history projects, students are supposed to adopt the ways in which historians work by researching the historical context; conducting, transcribing, analyzing, and interpreting the interview; and presenting the results (Bertram, Wagner \& Trautwein, 2017). Hickey (1999) claims that oral history projects are superior to traditional textbook approaches in three ways:

- Oral history is active, whereas textbook learning is passive.

- An oral history project takes students beyond the walls of the classroom to collect research by interviewing local residents and compiling information.

- Textbooks generally present only one side of a historical event, whereas the oral history approach encourages an examination of multiple perspectives of the same event.

The national social studies curriculum published in 2005 introduced oral history as a teaching method in Turkey. This curriculum aimed to develop students' abilities to engage in chronological thinking - to understand change and continuity in relation to time (MEB, 2005a; MEB, 2005b). The social studies curriculum updated in 2017 also includes oral history (MEB, 2017). Oral history studies contribute to the development of historical thinking skills (Dilek \& Alabaş, 2014) and historical awareness in children, enabling them to access new information that is not available in conventional sources, think critically, encounter new perspectives, and acquire research skills (Demircioğlu, 2007). In general, a number of surveys have shown that learning oral history methods positively impacts middle, high school, and university students (Sarı, 2007; Kaya 2013; Arslan, 2013; Kabapınar \& İncegül, 2016; Dilek, 2016). Teachers play an important role in using oral history as an effective method at school level. Therefore it is important to determine the experiences, opinions and attitudes of prospective teachers on oral history. In Turkey there are some studies demonstrating teacher candidates' views and attitudes about oral history. (Akbaba \& Kılcan, 2014; Demircioğlu, 2016; Dündar, 2017; Tural, 2017). In this study, prospective social studies teachers taking History of the Republic of Turkey course were asked to conduct oral history research on Turkey's recent history, and then their reactions to this experience were surveyed. The primary aim of the study was to determine how prospective social studies teachers evaluate their experiences conducting oral history regarding Turkey's recent history. To achieve this aim, the following research questions were developed:

1. How do prospective social studies teachers assess the effects of conducting oral histories about Turkey's recent history on their opinions about history?

2. What do prospective social studies teachers gain from completing oral histories related to Turkey's recent history?

3. What difficulties did prospective social studies teachers experience in conducting oral histories on Turkey's recent history?

4. What do prospective social studies teachers think about the oral history-based approach used in their History of the Republic of Turkey course?

5. Considering their oral history experiences, what do prospective social studies teachers think about teaching oral history practices in their future classrooms?

\section{Process}

This study was conducted in a course called History of the Republic of Turkey taught in the Faculty of Education's Social Studies Education Program at Sakarya University. Thirty-four prospective social studies teacher participated to the study. At the beginning of the semester, the researcher - as the lecturer responsible for the course -delivered a presentation titled "What is Oral History? How is it applied?" This class of prospective social studies teachers were asked to identify issues related to Turkey's recent history and individually conduct oral histories focusing on those issues. From the ninth week through the end of the class, they shared oral history experiences with other teacher candidates in ten-minute presentations. The prospective social studies teachers were required to turn in the oral history interviews they conducted along with their assessment reports during the last week of the course. At the end of the semester, semi-structured interviews were conducted with each of the 34 student teachers regarding their experiences completing the oral histories by the researcher. 


\section{Method}

\subsection{Research Design}

The study used phenomenological pattern qualitative research methods. Phenomenological studies describe the common meaning of several people's experiences with phenomena or concepts (Cresswell, 2015: 77). They focus on how people describe what they experience (Patton, 2014: 107). This study focused how prospective social studies teachers evaluated their experiences conducting oral histories regarding Turkey's recent history.

\subsection{Participants}

The research was conducted in a History of the Republic of Turkey course in the Faculty of Education at Sakarya University, located in the eastern part of the Marmara Region of Turkey. Sakarya University is qualified university and its students come from different parts of Turkey. The participants (20 female-14 male) were third-year students in the Social Studies Education Department. They were prospective social studies teachers enrolled in a course called History of the Republic of Turkey - a compulsory course in Turkish educational faculties. The course covered a period beginning with the establishment of the Turkish Republic and ending with recent political, social, and cultural events in Turkey. The prospective teachers who participated in the study had not previously taken any courses on oral history and therefore had no prior experience with oral history.

\subsection{Data Collection Toll}

Based on a phenomenological research design (a qualitative research method), the data were obtained via semi-structured interviews consisting of 5 questions developed for this study. The interviews were conducted after the participants delivered their presentations on their oral history research about Turkey's recent history. Experts in the field were consulted when developing the questions. Each prospective teacher was interviewed separately in January 2016, taking notes and making audio recordings of the sessions with a tape recorder.

Table 1. Participants' Oral History Research Topics about Recent History of Turkey

\begin{tabular}{lc}
\hline Oral History Application Topics & f \\
\hline September12, 1980 Military Strike & 18 \\
28 February Process & 5 \\
Cyprus Peace Operation & 3 \\
Turgut Özal Period & 3 \\
Village Institutes & 2 \\
Korean War & 1 \\
Decisions of January, 24 & 1 \\
1989 Bulgaria Immigrants & 1 \\
\hline Total & 34 \\
\hline
\end{tabular}

As Table 1 shows, more than half of the participants (f: 18) conducted oral history studies of the "September 12, 1980 Military Strike." The diversity of studies within this broad topic examples include "1980 Coup for a Soldier," "The Social Life of Peasants in the 1980 coup," and "1980 Coup for a child" - shows that the student teachers evaluated both the political and social dimensions of this incident. Participants answered questions related to oral history based on their experience completing the research topics listed in Table 1.

\subsection{Analysis of the Data}

In carrying out this research, voice recordings of the face-to-face interviews conducted with 34 prospective social studies teachers were made. Then the voice recordings were converted into text. Content analysis was used to analyze the data. Firstly they were coded and then the themes and sub-themes are specified within the framework of coding. In the analysis of the opinions of the teacher candidates, grouping was done taking the similarity of the expressions into account.

To ensure the credibility of the work (internal validity), an expert in the field was consulted regarding the analysis and coding of the data obtained from the interviews. In addition, the efficiency of the interview questions was evaluated on the basis of the fact that a participant was piloted. Reliability indicates that any data collection technique or tool will produce the same result every time the same feature is applied (Kıncal, 2014). In qualitative studies, a given code derived from data must mean the same thing for all participants. Two separate analyses of the data and coding were conducted to ensure consistency (internal reliability). Meanwhile, the above mentioned expert reanalyzed the data at a specific time to confirm its conformability (external reliability).

Following research ethics requirements, female teacher candidates were coded as F1, F2, F3....F20, and male teacher candidates were coded as M1, M2, and M3...M14. Participant responses were transcribed using these codes. 


\section{Results}

In this section, research findings according to the themes that identified in participant responses were divided. These themes were interpreted directly by quoting responses.

The first research question aimed to gauge how the prospective social studies teachers assessed the effects of completing oral history research about Turkey's recent history on their opinions about history. Table 2.1 presents the teacher candidates responses.

Table 2. The Effects of Conducting Oral Histories Regarding Turkey's Recent History on Participants' Thoughts about History

\begin{tabular}{|c|c|c|}
\hline Theme & Sub theme & $\mathbf{f}$ \\
\hline \multirow{8}{*}{ 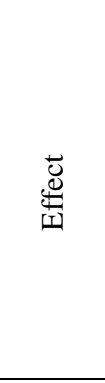 } & $\begin{array}{l}\text { Understanding that the everyday lives of ordinary people may be the subject of } \\
\text { history }\end{array}$ & 8 \\
\hline & $\begin{array}{l}\text { Understanding the necessity of evaluating historical events from different } \\
\text { perspectives }\end{array}$ & 6 \\
\hline & Feeling the influence of ideologies & 5 \\
\hline & Understanding the influence of historical events on people & 5 \\
\hline & Realizing the importance of historical research & 4 \\
\hline & Understanding that history is not just about written sources & 4 \\
\hline & Establishing historical empathy & 3 \\
\hline & Thinking that history science cannot be objective & 2 \\
\hline \multirow[t]{2}{*}{ 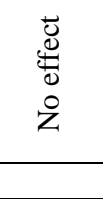 } & Ineffective & 2 \\
\hline & Total & 39 \\
\hline
\end{tabular}

As shown in Table 2, prospective social studies teachers' responses about conducting oral histories related to Turkey's recent history were divided broadly based on whether they reported that the experience had an "effect" or "no effect" on them. 8 sub-themes were derived from the effects participants reported.

Eight teacher candidates expressed sentiments that aligned with the phrase "I understand that the everyday lives of ordinary people can be the subject of history." F2's response exemplifies this sentiment: "I've seen how much history is in our daily lives. I noticed that not only the experts on the subject but also those who are not experts or who have not done any research on the subject may also have opinions about the history and that they can create ideas besides pure knowledge."

Six prospective social studies teachers expressed ideas that corresponded with the phrase "Understanding the necessity of evaluating historical events from different perspectives." F13's response serves as a useful example: "I did my work on oral history in relation to the 1980 coup d'état. I had little knowledge of the 1980 coup before conducting an oral history study, and I knew it from the infamous data of the 1980 coup. When I completed the oral history study, I realized that I have little knowledge of history and that I need to learn about different aspects of the event from different people. Because when I evaluated the 1980 coup d'état from the perspectives of rightists and leftists, I learned that both sides were very troubled."

Teacher candidates also stated that conducting oral histories related to Turkey's recent history in their establishing historical empathy and their thinking of history science cannot be objective.

Five prospective social studies teachers also emphasized the influence of ideologies and historical events. The responses of 4 teacher candidates corresponded to the phrases "I realized the importance of historical research" and "I understood that history is not just about written sources." M10's response connected these two ideas. "I understand the importance of historical research. I have seen that history is not just about written sources, but important information and experience can be reached in one-on-one meetings. I now think that the role of oral history in organized and non-formal education should be expanded. "

The second research question aimed to gauge what prospective social studies teachers gain from completing oral histories related to Turkey's recent history. Table 3 presents the teacher candidates' responses 
Table 3. Benefits Participants Derived from Completing Oral History Research Regarding Turkey’s Recent History

\begin{tabular}{llc}
\hline Theme & Sub theme & f \\
\hline & Different views & 13 \\
& Historical knowledge & 10 \\
& Motivation for learning history & 7 \\
& Knowledge of oral history & 5 \\
& Skill of empathy & 5 \\
& Method for learning history & 3 \\
& Experience of interview & 2 \\
\hline
\end{tabular}

As shown in Table 3 the prospective social studies teachers reported that their experience conducting oral histories related to Turkey's recent history exposed them to "different perspectives" and increased their "historical knowledge." F1 explained how the experience changed her perspective: "It changed my point of view about the events happening around me. Because what happens at this time will be history in the future. I can better understand why I'm looking back at the past. In this sense, oral history was a good experience for me." In a similar vein, F4 claimed that conducting an oral history expanded her historical knowledge: "I think that practicing oral history really benefited me. I once saw that what we know about our events in our books is not reflected to us, but to those who are aware of the effects of the events, which are not reflected in the books except for us. With this practice, many historical events did not come to light; I had the opportunity to learn about the parts that had been left out."

Seven teacher candidates indicated that their experiences conducting oral histories increased their "historical learning motivation." F7 said: "My interest in the subject has increased with my oral history study, and my interest in historical events has increased. It was a very valuable experience for me as I learned that there is a more formal narrative in books about the topic of conversation [Bulgarian Immigrants in 1989]." M11 emphasized that the experience helped him empathize with alternative points of view: "I was excited to tell about the 1980 period from the point of view of a person who experienced it or felt the influence of the events first hand. I had the opportunity to analyze that period very well. I empathized with the experiences of individuals with an ideology that is exactly the opposite of my own." Meanwhile, F18 pointed out that the experience enabled her to learn about both oral history and interview rhetoric: "Until this lesson I knew nothing about oral history. But with this lesson I learned a lot about oral history. For example, I had never interviewed anyone before. But thanks to the time I spent working on this oral history, I was able to have this experience."

The third research question aimed to quantify the difficulties the prospective social studies teachers encountered when conducting their oral histories regarding Turkey's recent history. Table 4 exhibits the teacher candidates' responses.

Table 4. Difficulties Participants Encountered when Conducting Oral Histories Regarding Turkey's Recent History

\begin{tabular}{lll}
\hline Theme & Sub Theme & f \\
\hline & To identify the source (find) & 8 \\
& & \\
\hline & Source persons' hesitation to speak & 8 \\
& Reaching source persons & 7 \\
& The source persons' getting out the topic & 5 \\
& The gendered approach of source persons & 3 \\
& Continuous emotional moments when the source persons tell their & 2 \\
\hline & stories & 2 \\
\hline
\end{tabular}

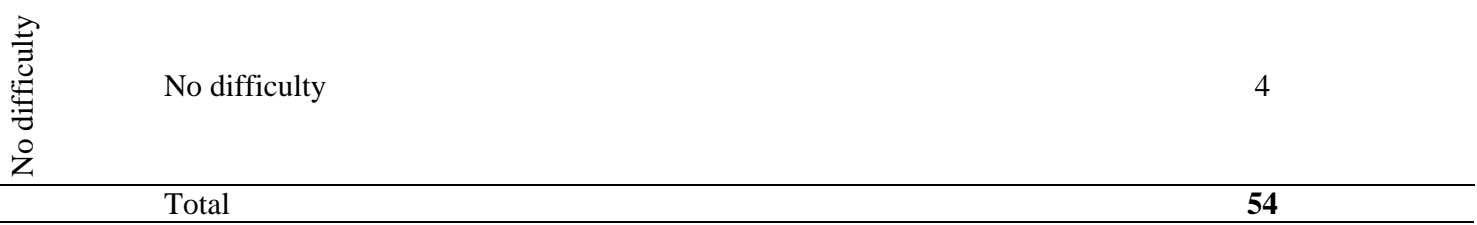

As shown in Table 4 the difficulties prospective social studies teachers experienced while conducting their oral histories were divided into three categories: "difficulties with source persons," "researcher difficulties" and "no difficulty."

Four prospective social studies teachers indicated that they encountered no difficulties in completing their oral histories. F4 connected the ease of the process to the topic she chose: "In fact, I did not have much difficulty. Which I think is 
relevant to what I'm dealing with. Because if I took the 1980 coup like my friends, I could face the hardships of my friends'. Because people are afraid to talk about that period. Both from the political dimension and from the tributes made at that time. But I did not have such a difficulty because my topic was about the economic decision on January 24th."

The difficulties were divided into two categories: difficulties related to source persons and difficulties related to the researcher. M11 described his difficulties to find source person as follows: "First, I wanted to choose the subject. But it was a bit difficult to find a person to do oral history work on the subject. For example, I was planning to have a meeting with a retired teacher first. However, as far as I can tell, the person did not speak out offear of being recorded. Later, I got a help from my friend and found another source person. But he did not allow the record in his speech about political matters."

F12's response exemplifies the gendered approach of source person: “... he was a bit anxiety with my questions because I was a lady. Obviously, trivia did not convey events that he had previously spoken to his peers."

Meanwhile, F9 highlighted common researcher-related challenges: "I had difficulty preparing the questions to be asked. Because the diversity of question was too much. Apart from that, I experienced emotional moments during the discussions. I had to stop the recording a few times. "

The fourth question aimed to gauge the prospective social studies teachers' opinions about the History of the Republic of Turkey's oral history lesson process. Table 5 shows the teacher candidates' views on this issue.

Table 5. Participants' Opinions about the History of the Turkish Republic Course's Oral History Process

\begin{tabular}{|c|c|c|}
\hline Theme & Sub Theme & $\mathbf{f}$ \\
\hline \multirow{5}{*}{$\sum_{\substack{0 \\
0}}^{\infty} \frac{\tilde{d}}{\infty}$} & Realization of active and permanent learning & 14 \\
\hline & Offered the opportunity to listen to different opinions & 13 \\
\hline & Increased interest in the course & 11 \\
\hline & Encouraged research & 5 \\
\hline & Generated a love of history & 4 \\
\hline \multirow{5}{*}{ 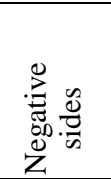 } & Did not stick to the textbook & 1 \\
\hline & Repetition of similar subjects & 5 \\
\hline & Failure to protect narrators' neutrality & 3 \\
\hline & Ignorance of political history & 2 \\
\hline & Time constraints & 1 \\
\hline \multirow{4}{*}{$\begin{array}{l}\infty \\
\infty \\
0 \\
\overline{0} \\
\tilde{\omega}\end{array}$} & Increasing topic diversity & 2 \\
\hline & Taking the source person of oral history to classroom & 1 \\
\hline & Achieving impartiality & 1 \\
\hline & Total & 63 \\
\hline
\end{tabular}

As shown in Table 5 the prospective social studies teachers' opinions about the History of the Turkish Republic course's oral history process were divided into three categories: "positive sides," "negative sides," and "suggestions." For positive sides, 14 of the prospective social studies teachers mentioned that the lesson enabled them to engage in active and permanent learning, 13 said the lesson gave them the opportunity to listen to different opinions, 11 said it increased their interest in the course, 5 mentioned that it encouraged their research efforts, 4 said it made them love studying history, and 1 pointed out that it freed them from sticking to the textbook.

F1's response exemplifies the teacher candidates' positive responses: "I think it was very good because it included us in the class. We were part of the lesson. We went from passive to active. With oral history, we listened to those who did not write in the books on the internet. We learned things we did not know. It grabbed our attention."

F13 emphasized that the lesson offered the opportunity to listen to different opinions: "I think our oral history work is much more lasting and impressive. Because both my own and my friends' work, I noticed that everyone learned a lot of different things. The most beautiful was that a right-winger learned something about the left-wing, or a left-winger learned something about the right-wing. And he was not laughing, not dying, respecting, and conveying this to the class. I believe that oral history work really adds something to us. It was an impressive, permanent, and fun work."

Describing his meeting with a Korean veteran, M8 said: "Hearing from the mouth of a person living in an incident that occurred in our history, the history of the Republic of Turkey, ended up by making us closer. Personally, I did not like studying recent history, but I started to like it because of the events that happened."

Regarding the lesson's negative sides, 5 of the social studies teachers mentioned the repetition of similar subjects, 3 highlighted the failure to protect the narrator's neutrality, 3 mentioned ignorance of political history, and 1 pointed out the lesson's time constraints.

Highlighting the failure to maintain the narrator's neutrality, M12 said: "Oral history is a really good practice in terms of our understanding of those days. Unfortunately, we have to rely on the information and resources in the state archives." 
With respect to time constraints, M11 said: "The positive side is that it was nice to tell the lesson with first hand resources. I think that it is a positive thing for students to examine periods or events from different perspectives. On the negative side, the superficial and repetitive explanation of topics became a time constraint."

Regarding the potential lack of impartiality, M3 said: "If we think about the negative side, we have seen each side of the story bear witness to the view of the other side and the views of the other side are prejudiced."

M1 highlighted ignorance of political history: "It is useful when we consider political history as a reflection of the human factor that has experienced the phenomenon that is not in the article and the book. However, it was not very useful to handle almost half of this lesson in this way. The concentration of the selected subjects on the 1980 coup d'état and on February 28th caused me to miss some subjects. He has already deprived the public of listening to the narrative of a society that has not already read and studied. "

In the suggestions category, M6 made the following recommendation: "the person to be spoken to should be brought to class. We chat with him and ask questions, and a friend makes a video recording."

The fifth research question aimed to quantify the prospective social studies teachers' opinions about introducing oral history practices in their future classrooms when they considered their own oral history experiences. Table 6 exhibits the teacher candidates' views on this issue.

Table 6. Participants' Opinions about Introducing Oral History Practices in their Future Classrooms

\begin{tabular}{|c|c|c|}
\hline Theme & Sub theme & $\mathbf{f}$ \\
\hline \multirow{6}{*}{ 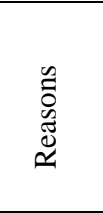 } & Bringing different perspectives & 7 \\
\hline & Clarifying matters in students' minds & 7 \\
\hline & Endearing histories & 5 \\
\hline & Motivating researches & 5 \\
\hline & Increasing intergenerational dialogue & 4 \\
\hline & Increasing historical knowledge & 1 \\
\hline \multirow{6}{*}{$\begin{array}{l}\frac{v}{8} \\
\frac{\Xi}{0} \\
\sum\end{array}$} & By inviting relevant source persons to the classroom & 10 \\
\hline & By ensuring that each student has a separate conversation & 10 \\
\hline & By selecting appropriate topics & 9 \\
\hline & By meeting family elders & 4 \\
\hline & By creating groups of $2-3$ people & 3 \\
\hline & Total & 65 \\
\hline
\end{tabular}

As shown in Table 6 prospective social studies teachers' opinions about introducing oral history practices into their future classrooms were divided into two categories: "reasons" and "methods." For reasons, 7teacher candidates mentioned bringing different perspectives, 7 emphasized clarifying matters in students' minds, 5 highlighted endearing histories, 5 mentioned motivating researches, 4 pointed to increasing intergenerational dialogue, and 1 discussed increasing historical knowledge.

For methods, 10 teacher candidates mentioned inviting relevant source persons to the classroom, 10 emphasized the importance of ensuring that each student has a separate conversation, 9 highlighted the selection of appropriate topics, 4 pointed to meeting family elders, and 3 discussed creating groups of 2-3 people.

F1 explained the following views on introducing the practice of oral history into his future classrooms: "Different experiences will change their perspectives. These practices will change traditional historical narratives and engage students in lessons with fun new experiences. I can also ask the students to talk to the people around them about their potential connections to subjects, and to touch on the points that interest them. Thus, students will be able to extract and concretize the history from the abstract and make them remain true. They will develop research and empathy skills."

Regarding the introduction of oral history practice into his future classrooms, M3 remarked: "Oral history is engaging, instructive, and enduring. I would like to have students research one by one and conduct interviews and share them with their classmates. Or, for example, I would like to divide the children into groups so that they can choose a theme, conduct interviews with the people who have lived with it, and submit it to the class."

M5 emphasized the potential for fostering intergenerational dialogue: "I certainly think about the practice of oral history. I can only explain the difference between us and the generation we are going to train with this method. This kind of practice can be done in every case of technology, politics and history."

\section{Conclusions and Recommendation}

This study evaluated prospective social studies teachers' experiences conducting oral history projects about Turkey's recent history in a course called History of the Republic of Turkey. Oral history, which involves consulting living witnesses from a given period, is widely acknowledged as among the most important methods of recording recent history. In this study, social studies teacher candidates acquired experience using oral history methods to collect 
information about recent history. Social studies curricula in Turkey place a great deal of emphasis on oral history; it is therefore very important that prospective teachers acquire experience with oral history as part of their training.

In this study, the majority of prospective teachers' oral histories focused on the "September 12, 1980 military coup." In addition to examining the political dimensions of the event, they conducted interviews about its economic, cultural, and social dimensions. These researches undoubtedly influenced the views of the prospective teachers. In particular, they learned that the daily lives of ordinary people can be the subject of history and that it is necessary to evaluate historical events from different perspectives; they also became more conscious of the effects - ideological and otherwise - of historical events on people. Conducting oral history researches about Turkey's recent history exposed the social studies teacher candidates to diverse points of view. In addition, the prospective social studies teachers who participated in this study indicated that this experience expanded their knowledge of both history and oral history, increased their motivation to learn more about history, further developed their empathic abilities, and introduced them to new methods for teaching history and conducting interviews. Dayton-Wodd, Hammonds, Matherson, \& Tollison (2012) likewise found that conducting oral histories increased students' knowledge of history and helped them develop interview skills. Belbağ and Balc1 (2017) emphasized that instruction in oral history practices in social studies classes helped students acquire knowledge, affective area and skills.

The prospective social studies teachers who participated in this study also discussed the difficulties they encountered in the process of completing their oral histories. These included: identifying and talking to sources, gender-related constraints, and unwillingness on the part of sources to have their stories recorded. Teacher candidates also reported that they encountered difficulties in their roles as researchers. These included: problems making recordings, selecting topics and preparing questions, and experiencing emotional moments during interviews. These results coincide with findings in Kurtdede-Fidan (2017) and Dündar (2017) regarding classroom teachers and Belbağ and Balcı (2017) regarding social history teachers and classroom oral history teachers. These studies primarily highlighted problems related to finding and contacting sources.

The prospective social studies teachers who participated in this study observed that History of the Republic of History course's oral history process had numerous benefits and several drawbacks. On the positive side, participants reported that the lesson enabled them to engage in active and permanent learning, gave them the opportunity to listen to different opinions, increased their interest in the course, encouraged them to undertake research, led them to develop a love for history, and exposed them to material outside the textbook. Regarding the lesson's downsides, participants highlighted the repeated focus on the same issues, the lack of impartiality on the part of narrators, and the fact that the course did not provide a complete overview of Turkey's political history. They proposed increasing topic diversity, bringing the oral history sources to the class, and taking steps to ensure impartiality.

The teacher candidates who participated in this study also gave a variety of rationales for integrating oral history lessons into their future classes. These included: exposing students to various perspectives, clarifying matters in students' minds, endearing history to students, motivating students to undertake research, increasing intergenerational dialogue, and expanding historical knowledge. They mentioned that they intended to employ the following methods when teaching oral history in the future: inviting source persons to class, choosing subjects appropriate for the class, and asking groups of 2-3 students to interview their family elders. These results are consistent with Demircioğlu's (2016) findings regarding history teacher candidates' perceptions of oral history; history teacher candidates in that study also found the oral history work valuable and indicated that they would like to practice it in their future class.

Based on this study's findings the following suggestions were developed:

- The number of lessons, seminars, and projects related to oral history in teacher education should be increased.

- Teachers from different branches should take in-service courses and seminars in oral history.

- Prospective teachers and students should be assigned projects designed to emphasize the social, cultural, and political dimensions of recent history.

- In addition to studies conducted with prospective teachers and teachers from different fields, scholars researching oral history should examine problems related to completing oral histories and suggest solutions.

- Scholars should also carry out studies comparing oral history research in Turkey and abroad.

\section{References}

Acun, F. (1998). Methodology of recent period history. Journal of Ataturk Research Center, 42, 717-756.

Akbaba, B., \& Kılcan, B. (2014). Prospective social studies teachers' attitudes towards oral history studies. Elementary Education Online, 13(3), 746-758.

Arslan, Y. (2013). The reflections of oral history on secondary school students (an example of Tunceli city center). 
Turkish History Educational Journal, 2(1), 1-29.

Beldağ, A., \& Balc1, M. (2017). Using oral history method in teaching social studies: A qualitive study. International Journal of Turkish Education Sciences, 5(9), 176-189.

Bertram, C., Wagner, W., Trautwein, U. (2017). Learning historical thinking with oral history interviews: A cluster randomized controlled intervention study of oral history interviews in history lessons. American Educational Research Journal, 54(3), 444-484. https://doi.org/10.3102/0002831217694833

Busby, R. S., \& Hubbard, J. D. (2007). Using local oral history in the elemantary classroom. Social Studies Research and Practice, 2(3), 367-386.

Çakmak, F. (2011). Determinations and problems in oral history: Bursa example. In Mehmet Öz,(Ed.) Proceedings: Symposium on Historiography and history publications in Turkey during the republican period (pp.545-555). Ankara: TTK Yayınları.

Caunce, S. (2001). Oral history and local historian. İstanbul: Tarih Vakfı Yurt Yayınları.

Cresswell, J. W. (2015). Qualitative research method: Qualitative research and research design according to five approaches. Ankara: Siyasal Kitabevi.

Crocco, M. S. (1998). Put in the actors back on stage: Oral history in the secondary school classroom. Social Studies, 89(1), 19-24. https://doi.org/10.1080/00377999809599817

Dayton-Wood, A., Hammonds, L., Matherson, L., \& Tollison, L. (2012). Bridging gaps and preserving memories through oral history, research and writing. English Journal, 101(4), 77-82.

Demircioğlu, E. (2017). Teacher candidates' attitudes to using oral history in history education. Journal of Education and Training Studies, 4(6), 184-191.

Demircioğlu, İ. H. (2007). Student-centred approaches in history teaching. Ankara: Anı Yayıncıl1k.

Dilek, D., \& Alabaş, R. (2014). Historical imagination. In M. Safran, (Ed.), How is history taught? Special teaching methods for history teachers (pp.125-131). Istanbul: Yeni İnsan Yayinevi.

Dilek, G. (2016). A study of oral and local history on sportswomen with $5^{\text {th }}$ grade students. Eurasian Journal of Educational Research, 16(63), 89-114. https://doi.org/10.14689/ejer.2016.63.6

Dündar, Ş. (2017). Preservice elementary school teachers' opinions related to oral history as a teaching method in social studies. Elementary Education Online, 16(4), 1621-1643. https://doi.org/10.17051/ilkonline.2017.342981

Dutt-Doner, K. M., Allen, S., Campanaro, K. (2016). Understanding the impact of using oral histories in the classroom. The Social Studies, 107(6), 257-265. https://doi.org/10.1080/00377996.2016.1221792

Güçlü, M. (2013). Application of oral history in history of education. Journal of Turkish Educational Science, 11(1), $100-113$.

Hickey, G. (1999). Bringing history home. Needham Heights. MA: Allyn and Bacon.

Huerta, G. C., \& Flemmer, L. A. (2000). Using student-generated oral history research in the secondary classroom. The Social Studies, 91(3), 110-115. https://doi.org/10.1080/00377990009602452

Jenks, C. E. (2010). Using Oral History in Elementary Classroom. Social Studies and Young Learner, 2(1), 31-32.

Kabapınar, Y., \& İncegül, S. (2016). Child games and toys within the framework of change and continuity: An oral history study. Turkish History Education Journal, 5(1), 74-96.

Kaya, M. (2013). Oral history as a teaching method that can be used in social studies lesson: Objective, content and application, (Unpublished master's thesis). Marmara University, Istanbul, Turkey.

Kincal, R. (2014). Scientific research methods. Ankara: Nobel Yayıncılık.

Kurtdede-Fidan, N. (2017). Opinions of classroom teachers about oral history method in social studies courses. Kastomonu Eğitim Dergisi, 25(1), 269-282.

MEB (2005a). Primary school social studies course $4^{\text {th }}-5^{\text {th }}$ grade curriculum. Ankara: Milli Eğitim Basımevi.

MEB (2005a). Primary school social studies course $6^{\text {th }}-7^{\text {th }}$ grade curriculum. Ankara: Milli Eğitim Basımevi.

MEB. (2017). Social studies course curriculum: Primary and middle school $4^{\text {th }}, 5^{\text {th }} 6^{\text {th. }}$ and $7^{\text {th }}$ grades. Downloaded from http://mufredat.meb.gov.tr/ProgramDetay.aspx?PID=354 on January, 1, 2018

Metin, C. (2002). Oral history and its developmet in Turkey. Journal of Turkish culture, 469, 288-298. 
Patton, M. Q. (2014). Oualitative research and evaluation methods. Ankara: Pegem Akademi.

Ritchie, D. A. (2003). Doing oral history: A practical guide. New York: Oxford University Press.

Ross, A. (1998). Children becoming historians: an oral history project in a primary school. In R.Perks and A. Thompson (Eds.). The oral history reader. London: Routledge.

Sağlam, M. (2010). Educational experiences of primary school students in the period 1970-1975: A study with oral history method, (Unpublished doctoral dissertation). Ankara University, Ankara, Turkey.

Sar1, İ. (2007). Effect of oral history activities on students achievement and attitudes in social studies teaching, (Unpublished doctoral dissertation). Gazi University, Ankara, Turkey.

Siler, C. R. (1996). Oral history in the teaching of U.S. history. ERIC Digest. ERIC Clearinghouse for Social Studies/Social Science Education Bloomington IN. Retrieved from the ERIC database. (ED393781)

Thomson, P., \& Bornat, J. The voice of the past: Oral history. New York: Oxford University Press.

Tural, A. (2017). Prospective social studies teachers' attitudes towards oral history studies. Bartin University Journal of Faculty of Education, 6(3), 1409-1419.

Yow, V. R. (2005). Recording oral history: A guide for the humanities and social sciences. Walnut Creek: Altamira Press.

\section{Copyrights}

Copyright for this article is retained by the author(s), with first publication rights granted to the journal.

This is an open-access article distributed under the terms and conditions of the Creative Commons Attribution license which permits unrestricted use, distribution, and reproduction in any medium, provided the original work is properly cited. 